\title{
DOAS measurements of formaldehyde and glyoxal above a south-east Asian tropical rainforest
}

\author{
S. M. MacDonald ${ }^{1}$, H. Oetjen ${ }^{1, *}$, A. S. Mahajan ${ }^{1, * *}$, L. K. Whalley ${ }^{1}$, P. M. Edwards ${ }^{1}{ }^{, * * *}$, D. E. Heard ${ }^{1}$, \\ C. E. Jones ${ }^{2, * * * *}$, and J. M. C. Plane ${ }^{1}$ \\ ${ }^{1}$ School of Chemistry, University of Leeds, Leeds LS2 9JT, UK \\ ${ }^{2}$ Department of Chemistry, University of York, Heslington, York, YO10 5DD, UK \\ * now at: The Department of Chemistry and Biochemistry, University of Colorado, Boulder, CO 80309-0215, USA \\ ** now at: The Laboratory for Atmospheric and Climate Science, CSIC-JCCM, 5007 Toledo, Spain \\ *** now at: NOAA ESRL, 325 Broadway R/CSD, Boulder, CO 80305-3337, USA \\ **** now at: Department of Applied Chemistry, Faculty of Urban Environmental Sciences, Tokyo Metropolitan University, \\ Minami-osawa 1-1, Hachioji-shi, Tokyo 192-0397, Japan
}

Correspondence to: J. M. C. Plane (j.m.c.plane@leeds.ac.uk)

Received: 22 December 2011 - Published in Atmos. Chem. Phys. Discuss.: 23 February 2012

Revised: 8 June 2012 - Accepted: 21 June 2012 - Published: 12 July 2012

\begin{abstract}
Tropical rainforests act as a huge contributor to the global emissions of biogenic volatile organic compounds (BVOCs). Measurements of their oxidation products, such as formaldehyde $(\mathrm{HCHO})$ and glyoxal $(\mathrm{CHOCHO})$, provide useful indicators of fast photochemistry occurring in the lower troposphere. However, measurements of these species in tropical forest locations are extremely limited. To redress this, $\mathrm{HCHO}$ and $\mathrm{CHOCHO}$ were measured using the longpath (LP) and multi-axis (MAX) differential optical absorption spectroscopy (DOAS) techniques above the rainforest canopy in Borneo during two campaigns in spring and summer 2008, as part of the Oxidant and Particle Photochemical Processes above a south-east Asian tropical rainforest (OP3) project. The results were compared with concurrent measurements of hydroxyl radical $(\mathrm{OH})$, isoprene $\left(\mathrm{C}_{5} \mathrm{H}_{8}\right)$ (which was the dominant organic species emitted in this forest environment), and various meteorological parameters. Formaldehyde was observed at a maximum concentration of $4.5 \mathrm{ppb}$ and glyoxal at a maximum of $1.6 \mathrm{ppb}$, significantly higher than previous measurements in rural locations. A 1-D chemistry model was then used to assess the diurnal evolution of formaldehyde and glyoxal throughout the boundary layer. The results, which compare well with the LP-DOAS and MAX-DOAS observations, suggest that the majority of the glyoxal and formaldehyde is confined to the first $500 \mathrm{~m}$ of the boundary layer, and that the measured ratio of these species
\end{abstract}

is reproduced using currently accepted product yields for the oxidation of isoprene by $\mathrm{OH}$. An important conclusion is that the measured levels of glyoxal are consistent with the surprisingly high concentrations of $\mathrm{OH}$ measured in this environment.

\section{Introduction}

Glyoxal (CHOCHO) is the smallest dicarbonyl and is produced in the atmosphere from the oxidation of a number of volatile organic compounds (VOCs). Biogenic sources include isoprene (47\% of the global source of glyoxal, Fu et al., 2008; Spaulding et al., 2003) and monoterpenes, while anthropogenic sources include aromatic compounds from vehicle emissions and biomass burning (Volkamer et al., 2001; $\mathrm{Fu}$ et al., 2008). Formaldehyde (HCHO) in the remote atmosphere is predominantly produced from the oxidation of methane by the hydroxyl (OH) radical (Arlander et al., 1995), but it is also produced through the oxidation of isoprene, which can be a dominant source depending on the emission rates (Dufour et al., 2009). Isoprene $\left(\mathrm{C}_{5} \mathrm{H}_{8}\right)$ is emitted by vegetation when exposed to sunlight, and the emission rate has a positive dependence on temperature. It is the most abundant non-methane VOC in the atmosphere, contributing $44 \%$ of the total atmospheric VOC flux (Guenther et al., 
1995). The tropical rainforests in South-East Asia act as a significant source of VOCs to the atmosphere; an estimated $10 \mathrm{Tg} \mathrm{C} \mathrm{yr}^{-1}$ of isoprene is contributed by the rainforests of Borneo alone compared to a global total of $\sim 500{\mathrm{Tg} \mathrm{C} \mathrm{yr}^{-1}}^{-1}$ (Guenther et al., 1995).

Both formaldehyde and glyoxal have been used as indicators for fast organic photochemistry occurring in the boundary layer (Volkamer et al., 2005a). Ground-based measurements of glyoxal are fairly sparse and have predominantly been in urban locations in the Northern Hemisphere, with comparatively few in rural environments. Measurements have been made using 2,4 dinitrophenylhydrazine coated annular denuders followed by high performance liquid chromatography (DNPH/HPLC) (Grosjean et al., 1990; Lee et al., 1998) and differential optical absorption spectroscopy (DOAS) (Volkamer et al., 2005a; Sinreich et al., 2007, 2010) with more recent measurements employing laser induced phosphorescence (Huisman et al., 2011) and incoherent broadband cavity enhanced absorption (Washenfelder et al., 2011). Satellite measurements (utilizing DOAS) have also been performed using both the SCIAMACHY (SCanning Imaging Absorption spectroMeter for Atmospheric CartograpHY) and GOME-2 (Global Ozone Monitoring Experiment-2) instruments (Wittrock et al., 2006; Vrekoussis et al., 2009; Lerot et al., 2010). The concentrations of glyoxal in the boundary layer range from parts per trillion (ppt, equivalent to $\mathrm{pmol} \mathrm{mol}^{-1}$ ) to low parts per billion (ppb, equivalent to nmol mol${ }^{-1}$ ) levels, with higher concentrations observed in highly polluted urban environments (Volkamer et al., 2005a) and areas with high biogenic activity (Wittrock et al., 2006; Vrekoussis et al., 2009), while low concentrations have been reported in remote environments (Sinreich et al., 2010). Very recent measurements of glyoxal above a pine plantation in the Sierra Nevada using LaserInduced Phosphorescence (LIP) found daytime peak glyoxal mixing ratios of 50-150 ppt (Huisman et al., 2011).

Atmospheric measurements of formaldehyde are much more abundant. A number of different measurement techniques have been employed and inter-compared (Hak et al., 2005; Cardenas et al., 2000). Concentrations of formaldehyde in rural locations are typically in the $0.1-4 \mathrm{ppb}$ range (Munger et al., 1995; Lee et al., 1998; Heikes, 1992; Lowe and Schmidt, 1983), with much higher concentrations (up to $29 \mathrm{ppb}$ ) in urban locations (Possanzini et al., 2002; Grosjean, 1991). Measurements of HCHO above a pine forest in the US Sierra Nevada using Quantum Cascade Laser Spectroscopy (QCLS) showed elevated levels of 15-20 ppb at midday attributed to abundant emissions of very reactive volatile organic compounds (Choi et al., 2010).

Satellite measurements indicate significant levels of glyoxal and formaldehyde over the tropical oceans (Wittrock et al., 2006), and recent ship-based measurements in the southeastern Pacific reported up to $140 \mathrm{ppt}$ of glyoxal above the ocean surface (Sinreich et al., 2010). In fact, these measurements cannot be fully explained using the current knowledge of glyoxal source and sink chemistry. The lifetime of glyoxal is of the order of $1-2 \mathrm{~h}$ for overhead sun conditions in urban environments (Volkamer et al., 2005a), or 2-3 h globally (Myriokefalitakis et al., 2008; Fu et al., 2008), and is determined primarily by photolysis and reaction with $\mathrm{OH}$ (Volkamer et al., 2005a). The importance of glyoxal in secondary organic aerosol (SOA) formation has been an area of increased interest recently; questions remain over the mechanism of glyoxal uptake (Corrigan et al., 2008; Kroll et al., 2005; Liggio et al., 2005). Fu et al. (2008) found that glyoxal loss to aerosol in an urban environment was comparable to oxidation by $\mathrm{OH}$, and aerosol loss accounted for a significant missing sink identified from modelling glyoxal measurements in Mexico City (Volkamer et al., 2007). Measurements have also shown that the extent of glyoxal uptake is heavily dependent on the coating of the seed aerosol (Galloway et al., 2011b; Volkamer et al., 2009). Glyoxal uptake may also account for the missing source of SOA in the free troposphere identified in current global models such as GEOS-Chem (Heald et al., 2005). Recent studies have shown that glyoxal processing in clouds could provide a further source of SOA to the free troposphere (Tan et al., 2009).

The average lifetime of formaldehyde in the troposphere is around $5 \mathrm{~h}$ (Arlander et al., 1995), and is similarly governed by its reaction with $\mathrm{OH}$ and photolysis. Although uptake of formaldehyde occurs on acidified aerosol, it should not play a role in SOA formation under typical atmospheric conditions (Jayne et al., 1996; Kroll et al., 2005). Smaller loss processes for both species are dry and wet deposition, due to their high solubility in water (Fu et al., 2008).

Satellite measurements indicate increased concentrations for both species over areas with high biogenic isoprene emissions (Wittrock et al., 2006). These measurements also suggest that the ratio of glyoxal to formaldehyde can be an indicator of whether the sources of these species are predominantly biogenic or anthropogenic: higher ratios indicate a greater influence of biogenic activity. A ratio of 0.06 was determined for areas where biogenic sources dominate such as tropical rainforests (Vrekoussis et al., 2010), compared to a ratio of 0.04 in urban environments.

In this paper we describe ground-based measurements of glyoxal and formaldehyde over a tropical rainforest canopy, using long-path DOAS (LP-DOAS) and multi-axis DOAS (MAX-DOAS) instruments. The observed diurnal variations and ratios of the two compounds are then interpreted using a 1-dimensional model of the boundary layer above the forest canopy.

\section{Field campaigns and measurement techniques}

Measurements were performed during two campaigns in April/May and June/July 2008, as part of the Oxidant and Particle Photochemical Processes above a south-east Asian tropical rain forest (OP3) project. During these campaigns a 


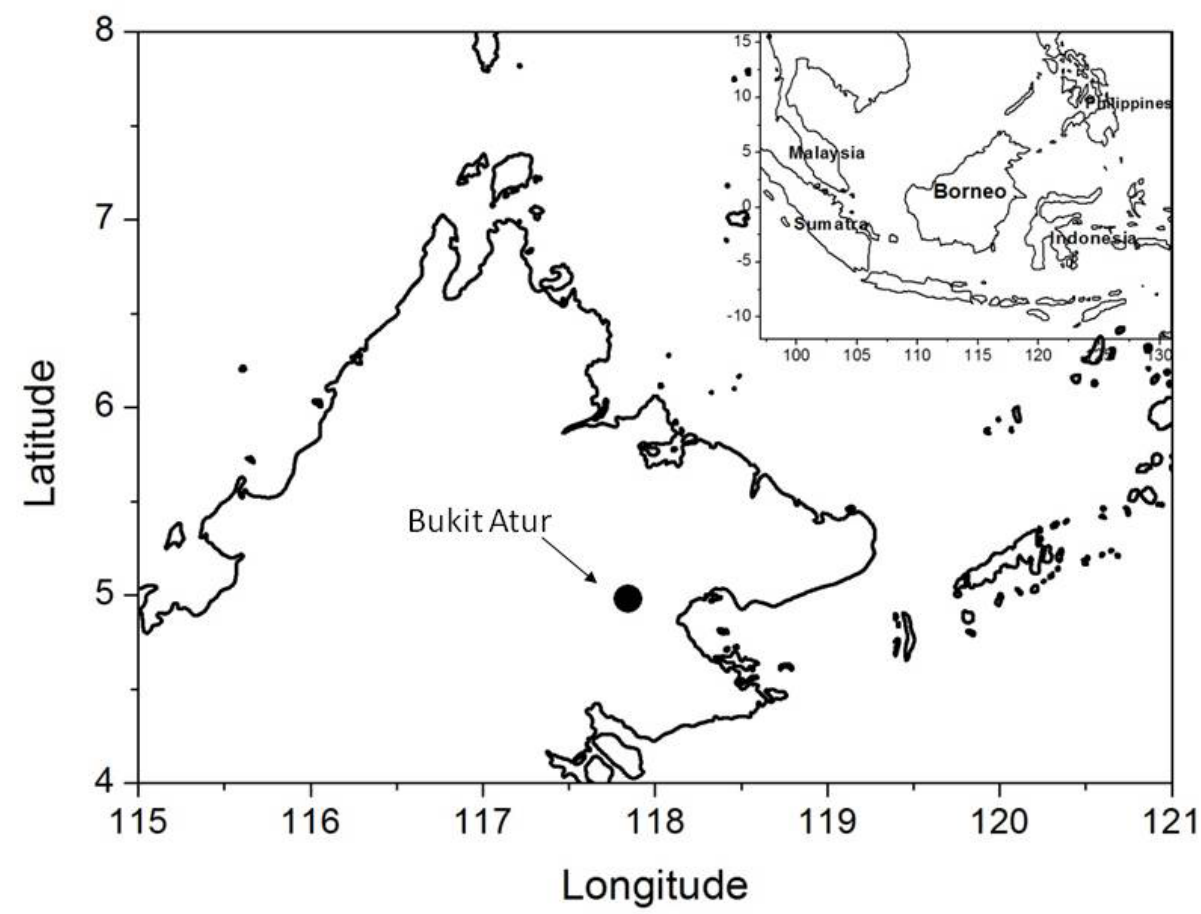

Fig. 1. Coastline of Borneo with measurement site indicated by the black dot and inset showing the location of Borneo within south-east Asia.

variety of ground-based and airborne techniques were used to study the atmospheric composition within and above the rainforest canopy (Hewitt et al., 2010). The LP-DOAS instrument was located on a look-out tower at Bukit Atur in Danum Valley, Sabah, Malaysia ( $\left.4^{\circ} 58^{\prime} 49.33^{\prime \prime} \mathrm{N}, 117^{\circ} 50^{\prime} 39.05^{\prime \prime} \mathrm{E}\right)$ (Fig. 1). The Bukit Atur Global Atmospheric Watch (GAW) tower is situated within the Danum Valley Conservation Area, which covers an area of $438 \mathrm{~km}^{2}$ of protected rainforest. The site is located approximately $30 \mathrm{~km}$ from the coast and $70 \mathrm{~km}$ south-west of the Sabahmas palm oil plantation (Hewitt et al., 2010).

The LP-DOAS optical path was directed $3.35 \mathrm{~km}$ southwest at an elevation angle of $-3^{\circ}$ to the top of the canopy (Fig. 2), where an array of corner cube reflectors was secured to the trunk of a tree $40 \mathrm{~m}$ above the ground in the forest canopy. The total optical path length was $6.7 \mathrm{~km}$, running at an average height of about $90 \mathrm{~m}$ above the canopy taking into account the difference in height between the retroreflector and the hill on which the LP-DOAS was situated ( $180 \mathrm{~m}$ higher). There is a further discussion of the height difference between the DOAS and complementary measurements in the discussion and modelling section. Details of the instrument and spectral deconvolution procedure can be found elsewhere (Plane and Saiz-Lopez, 2006), and so only a brief description is presented here. Spectra were recorded using a $0.5 \mathrm{~m}$ Czerny-Turner spectrometer with a 1200 grooves $\mathrm{mm}^{-1}$ grating, coupled to a cooled CCD camera, producing a spectral resolution of $0.25 \mathrm{~nm}$ in a spectral region spanning about $40 \mathrm{~nm}$. A $400 \mathrm{~W}$ xenon arc lamp was used as the light source. Reference lamp spectra were recorded online at $30 \mathrm{~s}$ intervals using an optical bypass system allowing for measurement of light that was not exposed to the atmospheric lightpath. A similar system enabled recording of the background light by blocking the Xe arc lamp source. Spectra were averaged for 10 and $60 \mathrm{~min}$ for glyoxal and formaldehyde, respectively, to improve the signal-to-noise. The spectra were then converted into optical densities and the contributions of the individual absorbing species were determined by simultaneously fitting, using singular value decomposition, a library of reference absorption cross sections to determine their respective concentrations (Plane and Saiz-Lopez, 2006).

An important point to note is that simultaneous measurements of glyoxal and formaldehyde are not possible with this specific instrument, because these species are retrieved in different, not simultaneously probed spectral regions. Glyoxal was measured in the visible from $412-454 \mathrm{~nm}$. The spectral fitting window used was from $422-442 \mathrm{~nm}$ and reference spectra fitted in this region were glyoxal (Volkamer et al., 2005a), $\mathrm{NO}_{2}$ (Vandaele et al., 1998) and $\mathrm{H}_{2} \mathrm{O}$ (Rothman et al., 2003). Formaldehyde was measured in the near-UV from $316-358 \mathrm{~nm}$ and the spectral fitting range used was from $324-356 \mathrm{~nm}$. The reference spectra fitted in this window were formaldehyde (Meller and Moortgat, 2000), $\mathrm{NO}_{2}$ (Vandaele et al., 1998) and $\mathrm{O}_{3}$ (Burrows et al., 1999). Figure 3 illustrates examples of spectral fits for glyoxal and formaldehyde. The detection limit for glyoxal was between 100$200 \mathrm{ppt}$ (depending on visibility), and that for formaldehyde 


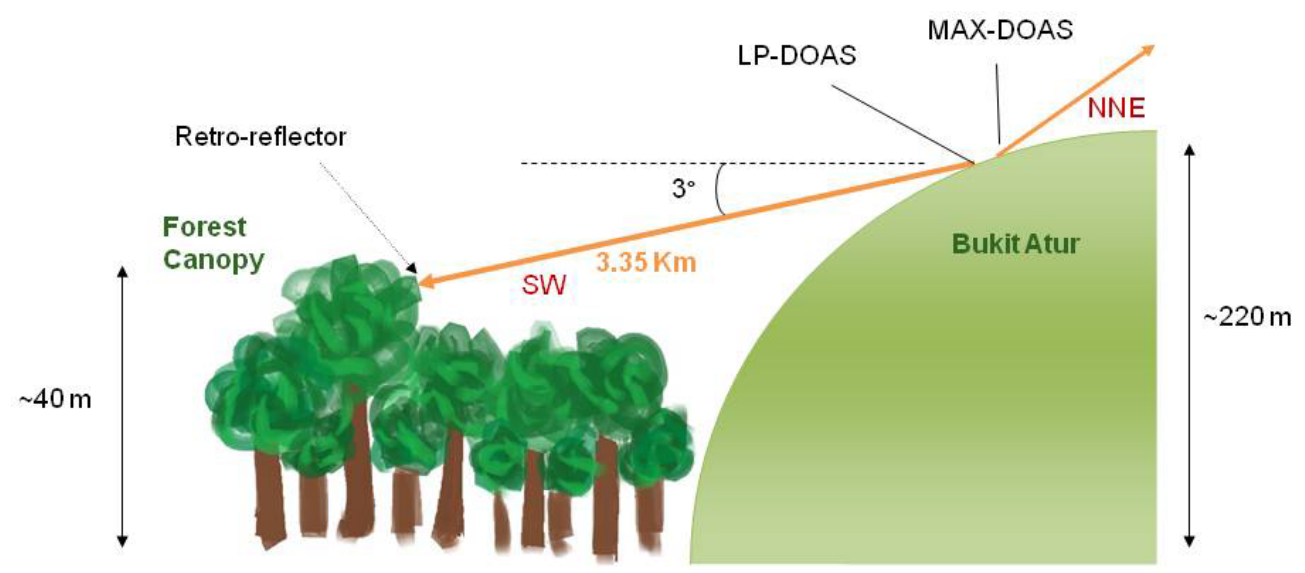

Fig. 2. Schematic diagram of the field site showing viewing directions for both DOAS instruments.

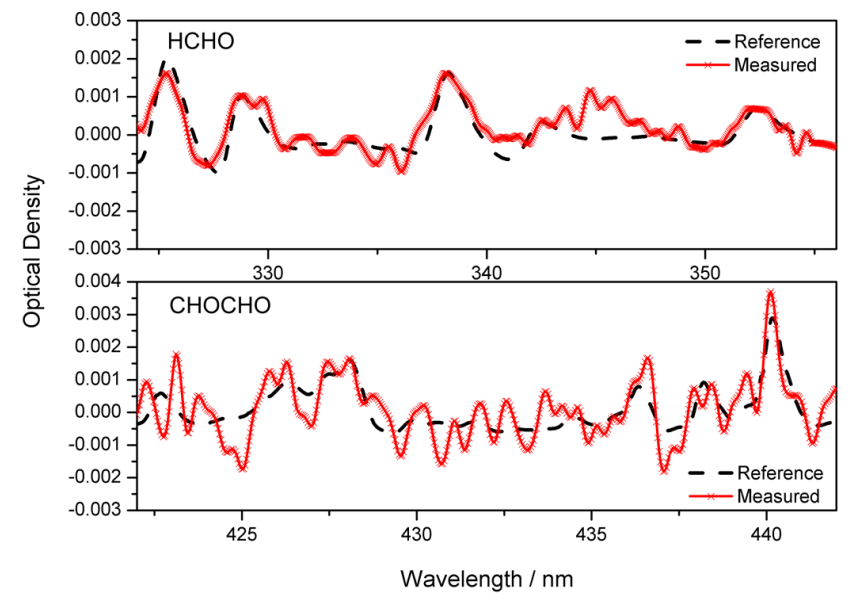

Fig. 3. Example spectral fits for formaldehyde and glyoxal from the LP-DOAS analysis. The red solid lines and markers show the measured atmospheric spectrum after all other absorbers have been subtracted and the dashed lines show the respective reference spectra for $\mathrm{HCHO}$ and $\mathrm{CHOCHO}$, corresponding to $2452 \pm 74 \mathrm{ppt}$ and $764 \pm 72$ ppt, respectively.

between 300 and 400 ppt. The residual structures present in the spectrum appear to be random and do not appear systematically in successive spectra.

The MAX-DOAS instrument was situated on the same tower at Bukit Atur as the LP-DOAS instrument, but viewing north-north-east (Fig. 2) as this gave the lowest possible viewing angle over the forest canopy. The MAX-DOAS technique uses scattered sunlight as the light source, and spectra are recorded at discrete viewing angles so that vertical profile information on the species of interest can be obtained (Plane and Saiz-Lopez, 2006; Platt and Stutz, 2008). The Leeds MAX-DOAS employs a stepper motor to scan the elevation angle of a small telescope, at a fixed azimuthal angle. The telescope consists of a $2.5 \mathrm{~cm}$ diameter quartz lens with a $7.5 \mathrm{~cm}$ focal length, whose focal point is the entrance to an

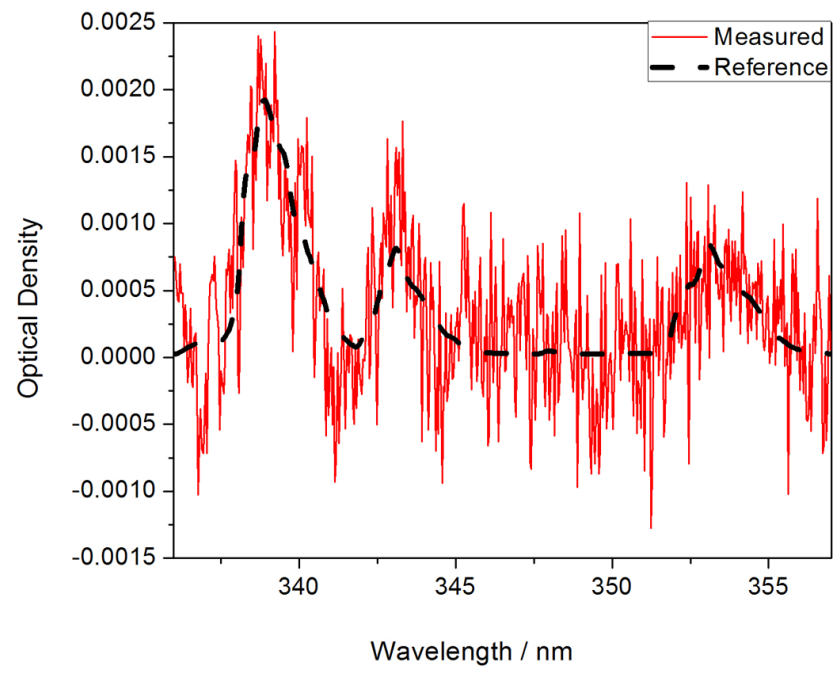

Fig. 4. Example spectral fit for formaldehyde from the MAX-DOAS analysis. The red solid line shows the measured atmospheric spectrum after all other absorbers have been subtracted, and the dashed line shows the reference spectrum. The fit corresponds to a slant column density of $3.31 \times 10^{16} \mathrm{~cm}^{-2}$ and is for a solar zenith angle of $59^{\circ}$.

optic fibre. This arrangement has a field of view around $1^{\circ}$. Spectra were recorded at 9 discrete viewing angles: 1, 2, 4, $6,8,10,15,30$ and $90^{\circ}$ elevation, with $30 \mathrm{~s}$ exposure time at each angle. Formaldehyde was measured in the $326-369 \mathrm{~nm}$ spectral region. Along with the HCHO absorption cross section, the other species fitted in the window from $336-357 \mathrm{~nm}$ were $\mathrm{BrO}, \mathrm{NO}_{2}, \mathrm{O}_{3}, \mathrm{O}_{4}$, and a Ring spectrum (Greenblatt et al., 1990; Meller and Moortgat, 2000; Vandaele et al., 1998; Wilmouth et al., 1999; Bogumil et al., 2003) and the zenith spectrum from each scan is used as a reference. An example of a MAX-DOAS spectral fit is shown in Fig. 4.

In addition to the DOAS measurements, there was a comprehensive suite of instruments measuring various species 


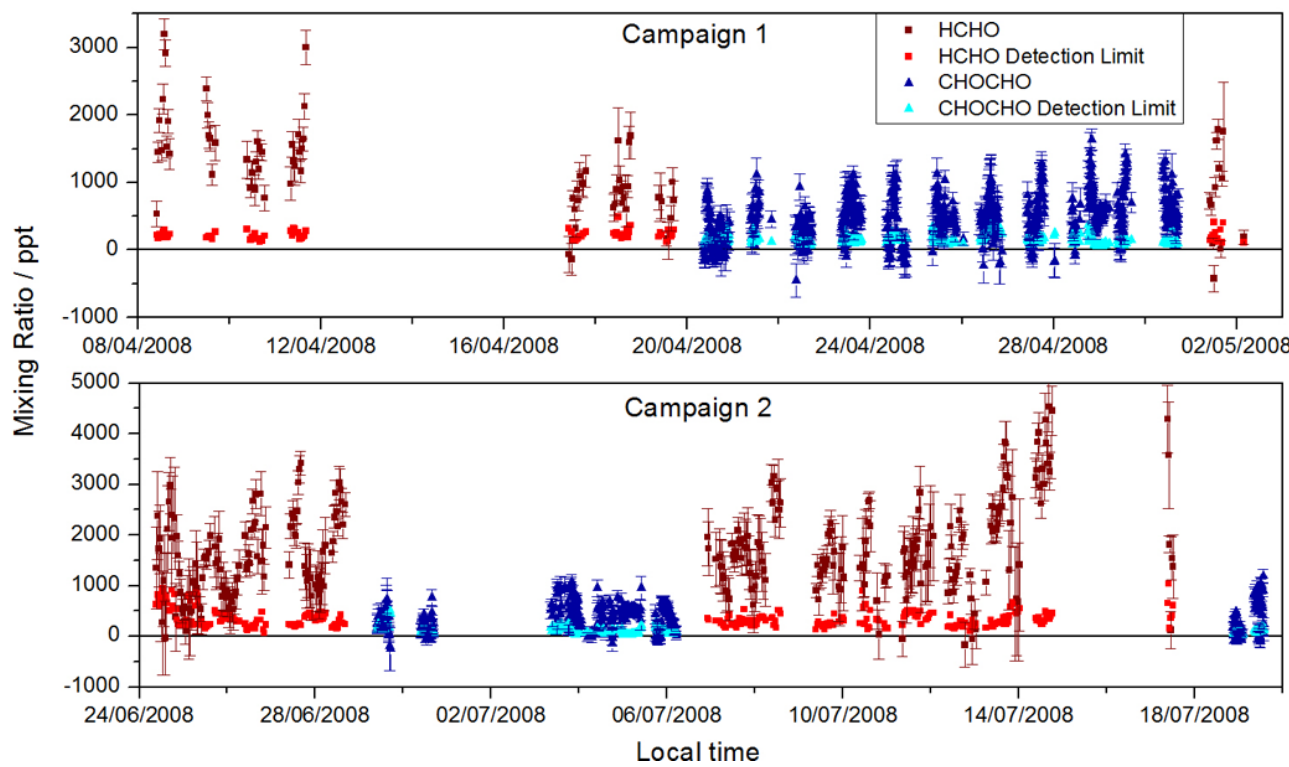

Fig. 5. Time series for formaldehyde and glyoxal over both campaigns. The red squares show the measured formaldehyde and the associated detection limit and the blue triangles are those for glyoxal.

at the Bukit Atur site. OH measurements were made using the Fluorescence Assay by Gas Expansion (FAGE) technique (Whalley et al., 2011) and measurements of aerosol surface area were performed using a Differential Mobility Particle Sizer (DMPS) (Winklmayr et al., 1991). Measurements of isoprene were made using Gas Chromatography with Flame Ionisation Detection (GC-FID) at $5 \mathrm{~m}$, on top of the FAGE container and with Proton Transfer Reaction Mass Spectrometry (PTRMS) at $75 \mathrm{~m}$ on the GAW tower (Langford et al., 2009; Hopkins et al., 2003).

\section{Observations}

Figure 5 summarises the results from the LP-DOAS for both campaigns. Glyoxal was measured on 19 days. It showed significant variability, from below the detection limit (100$200 \mathrm{ppt}$ ) at night up to typically $800-1000 \mathrm{ppt}$ during the day. The maximum value observed was $1.6 \mathrm{ppb}$ on 28 April. The diurnal peak in glyoxal was highly variable and was observed from 11:00 LT until well into the night as late as 21:00 LT, after the isoprene concentration had dropped close to zero on some days. There was usually a lack of retrievable data in the early hours of the morning due to the presence of fog which persisted on many of the days of measurements; however, there were 6 days when glyoxal was observed above the detection limit throughout the night. It should be noted that the negative concentration values in Fig. 5 resulted from the DOAS fitting procedure to spectra with low signal-to-noise, which usually resulted from reduced visibility. Large variations in the shift and stretch required to fit the spectra were required due to the unstable temperature in the LP-DOAS container. The fitting was improved by calculating the shift and stretch for each spectrum online in the analysis program.

Formaldehyde was observed on 23 days over both campaigns. The maximum value of $4.5 \mathrm{ppb}$ was observed during the second campaign on 14 July; the typical daytime peak concentrations were $2-3 \mathrm{ppb}$ (Fig. 5). The formaldehyde concentrations generally peaked after midday from around 14:00 to 17:00 LT, with a gradual decrease into the evening.

Formaldehyde was also observed using the MAX-DOAS instrument on 9 days in the first campaign and 16 days in the second campaign (Fig. 6). The slant column densities were found to vary from below the detection limit up to a maximum of around $10 \times 10^{16} \mathrm{~cm}^{-2}$. Typical values for the $2 \sigma$ uncertainty and $2 \sigma$ detection limit are $6 \times 10^{15}$ and $3.4 \times 10^{16}$ for $\mathrm{SZA}<80^{\circ}$, and $3 \times 10^{15}$ and $2 \times 10^{16} \mathrm{~cm}^{-2}$ for SZA $<60^{\circ}$.

It is clear from Fig. 7 that the majority of the formaldehyde is observed in the lowermost elevation angles, meaning the formaldehyde is contained within the first few hundred metres above the canopy and that the highest formaldehyde slant columns are observed in the late afternoon, confirming the LP-DOAS observations. A geometrical conversion of the slant column densities for the $2^{\circ}$ elevation angle assuming the formaldehyde is uniformly distributed in a layer $250 \mathrm{~m}$ above the canopy gives reasonable agreement with the LPDOAS formaldehyde measurements (Fig. 8). A correlation of the LP against the MAX-DOAS data sets gave a correlation coefficient of only 0.016 . Reasons for this low value include the fact that the two instruments were sampling different air masses with highly variable topography due to their differing viewing directions. A full inversion of the slant columns using radiative transfer is not possible for all the data due to the constant presence of patchy clouds contaminating the 


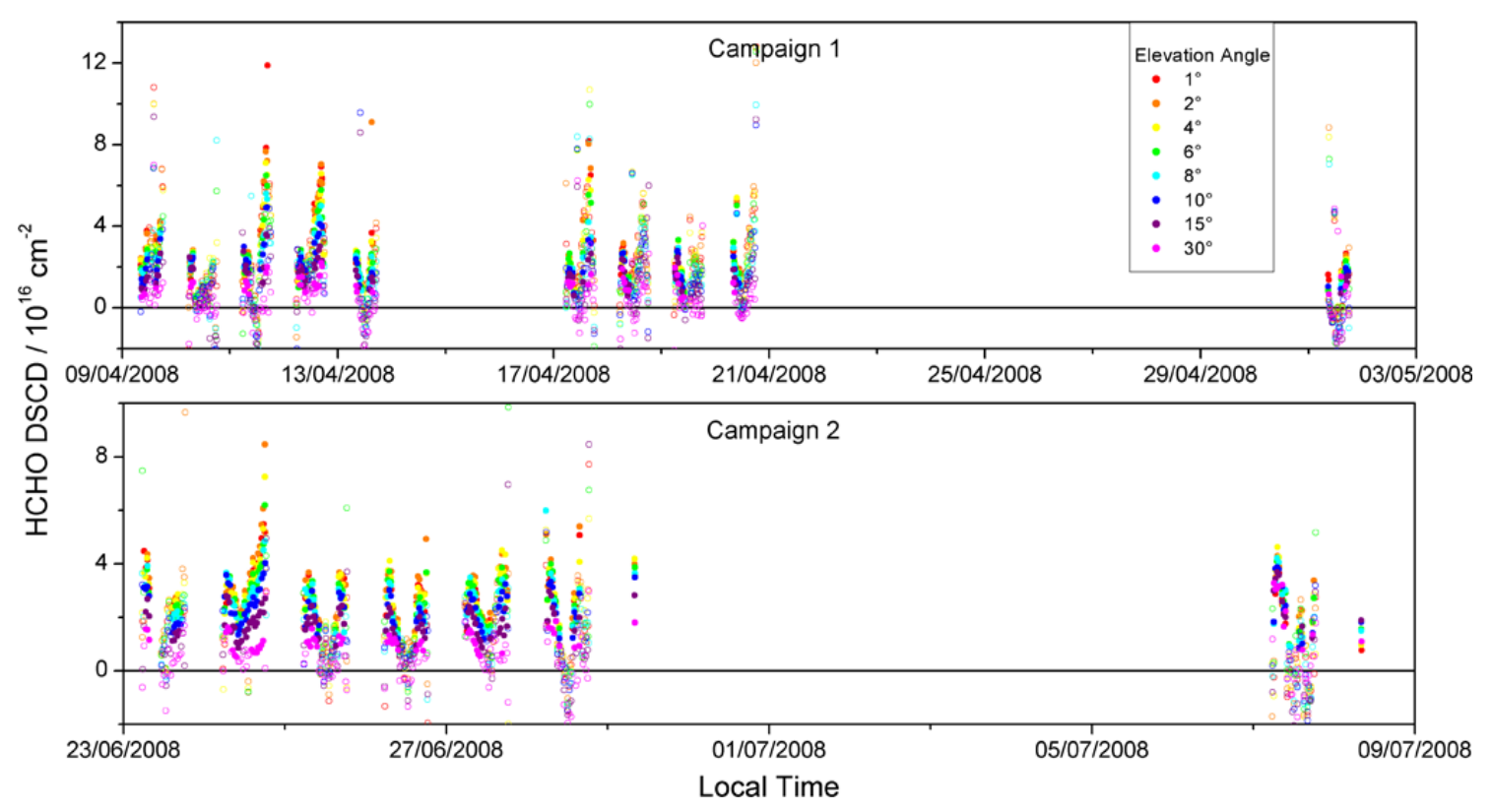

Fig. 6. Time series for formaldehyde measured using the MAX-DOAS over both campaigns. The solid circles represent data above the detection limit while the open circles represent data which were below the detection limit or when there was significant cloud.

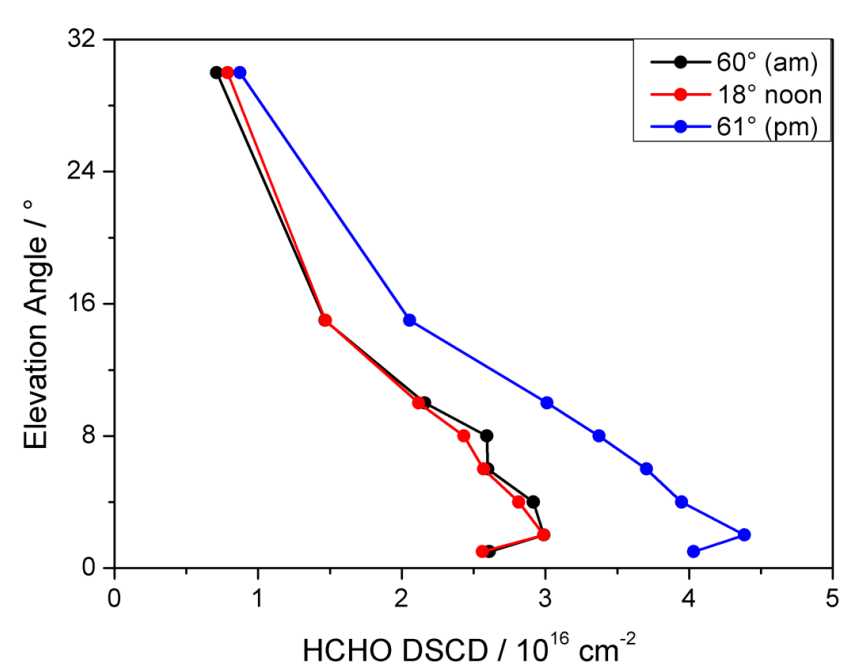

Fig. 7. HCHO differential slant column density vs. viewing angle on 24 June 2008 for 3 different solar zenith angles: $60^{\circ}$ (around 08:00 LT - black), $18^{\circ}$ (noon - red) and $61^{\circ}$ (around 16:00 LT blue). Note the large increase in $\mathrm{HCHO}$ between the two profiles with solar zenith angles $=60^{\circ}$. The noon profile exhibits a comparatively small slant column density because the solar zenith angle is only $18^{\circ}$.

higher elevation angles; however, using one relatively cloud free day a full inversion was applied which gave good agreement with the geometric conversion. Vertical column densities were obtained using the $15^{\circ}$ elevation angle. The average values ranged from $2 \times 10^{15}$ to $7 \times 10^{15} \mathrm{~cm}^{-2}$, in good agreement with the SCIAMACHY satellite vertical columns of $5 \times 10^{15} \mathrm{~cm}^{-2}$ for July at this location. The errors in the monthly averaged satellite $\mathrm{HCHO}$ slant columns were typically around $2.5 \times 10^{15} \mathrm{~cm}^{-2}$ (Wittrock et al., 2006).

\section{Discussion and modelling}

The observations of glyoxal are significantly higher than previous measurements in rural environments where typical maximum mixing ratios range from around $140-350 \mathrm{ppt}$ (Huisman et al., 2011; Sinreich et al., 2007; Munger et al., 1995; Lee et al., 1998). However, none of these measurements were in tropical locations, where there should be a higher concentration of precursor species such as isoprene, with the exception of Huisman et al. (2011) which had very similar isoprene concentrations and also high levels of the glyoxal precursor MBO. The formaldehyde measurements show good agreement with previous ground-based measurements in rural locations where mixing ratios of around 0.14 ppb have been recorded (Lee et al., 1998; Munger et al., 1995; Lowe and Schmidt, 1983; Heikes, 1992), and airborne measurements over the Amazon rainforest which were typically around 1-2 ppb (Stickler et al., 2007), although the peak concentrations are lower than those observed by Choi et al. (2010) above a pine plantation which ranged from 1520 ppb.

Glyoxal was found to have some dependence on rainfall; due to its high solubility, it was generally washed out during periods of rainfall which were frequent but very inhomogeneous over Danum Valley (Fig. 9). Both formaldehyde and glyoxal generally peaked in the afternoon several hours 


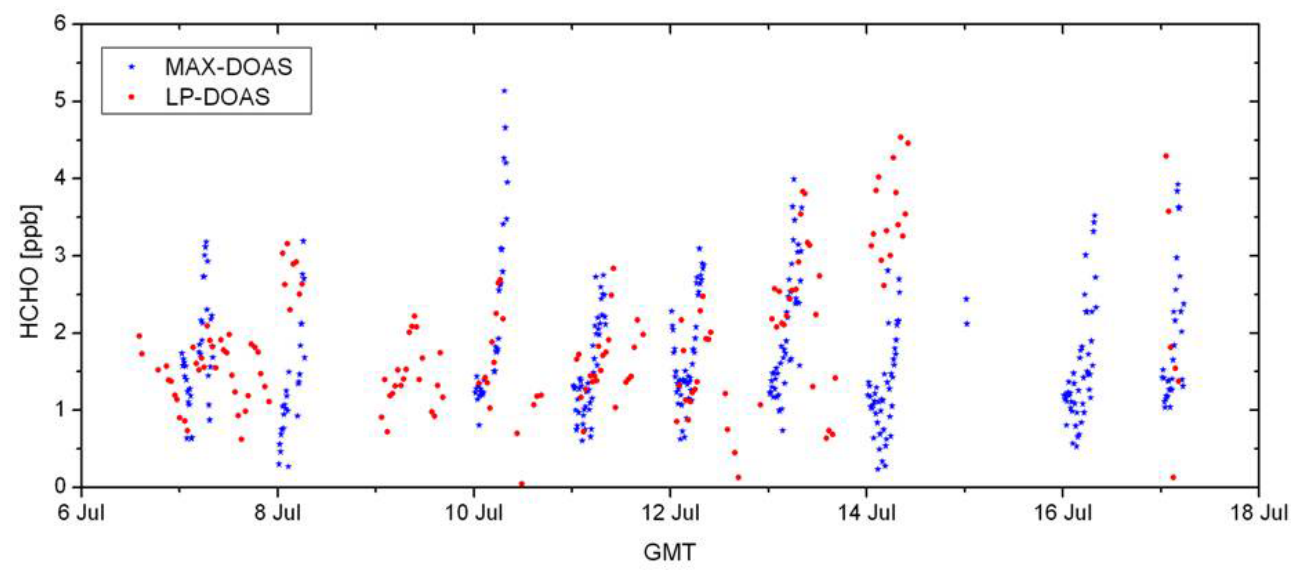

Fig. 8. Geometric conversion of the MAX-DOAS slant column densities at $2^{\circ}$ elevation angle to mixing ratios assuming a block profile of $250 \mathrm{~m}$ thickness, which are then compared with simultaneous LP-DOAS measurements.

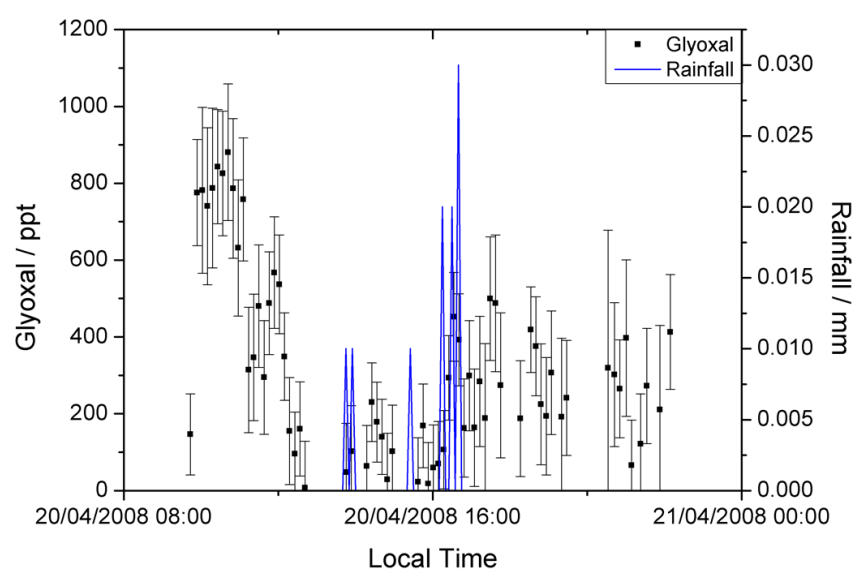

Fig. 9. LP-DOAS measurements of glyoxal (black squares) on 20 April 2008 showing a sharp drop in the middle of the day during an episode of rainfall measured at the GAW tower (blue lines). Missing data points are due to poor visibility for DOAS measurements caused by the rainfall. Note that because of the localised nature of the showers, the anti-correlation is not precise.

after the peak in the isoprene concentration, as can be seen in Fig. 10. The larger concentrations of glyoxal through the late evening after the drop in the modelled values may be due to alternative sources of glyoxal such as monoterpenes. Measurements of monoterpenes during the two campaigns showed that they were consistently present throughout the night, unlike isoprene, and could represent a source of glyoxal in the evening.

The SCIAMACHY observations made in 2007 indicate that the glyoxal concentration in the forest canopy was in the range 460-640 ppt, assuming that the glyoxal was contained within the first $500 \mathrm{~m}$ of the boundary layer (Vrekoussis et al., 2009). Given that these satellite measurements were made at around 10:00 LT (i.e., about $5 \mathrm{~h}$ before the gly- oxal concentration tends to peak), these results are consistent with the LP-DOAS observations in the present study.

A model with a simplified chemistry scheme was then used to investigate whether the observations of glyoxal and formaldehyde could be reproduced solely from isoprene oxidation by $\mathrm{OH}$, at the levels of $\mathrm{OH}$ which were measured during the OP3 campaign (Whalley et al., 2011). Isoprene was the dominant precursor species measured above the forest canopy - the total monoterpene to isoprene ratio was 0.2 0.25 measured over both campaigns (Jones et al., 2011). An existing 1-D chemistry/transport model (Saiz-Lopez et al., 2008) was used with a simplified organic chemistry scheme. This scheme included oxidation of isoprene by $\mathrm{OH}$ as a source for both glyoxal and formaldehyde, and included loss of both species by reaction with $\mathrm{OH}$, photolysis, and uptake onto aerosol.

The vertical resolution of the model was $5 \mathrm{~m}$ with a boundary layer height of $1 \mathrm{~km}$ (typical of measurements at the site during daytime, Pearson et al., 2010) which was kept constant throughout the model runs. Although the lidar measurements made during the campaign showed evidence of the boundary layer collapsing to $200 \mathrm{~m}$ after midnight, this coincided with the episodes of fog observed at the site when fewer LP-DOAS measurements are available. Vertical transport of all species was governed by eddy diffusion between boxes. The eddy diffusion coefficient $K_{z}$ was estimated from the wind speed measurements recorded on the GAW tower at heights of 30, 45 and $75 \mathrm{~m}$, and assuming a surface roughness length of $2.2 \mathrm{~m}$ (Jacobson, 2005). The values for $K_{z}$ ranged from $6.4 \times 10^{3}$ at the ground to $5.0 \times 10^{4} \mathrm{~cm}^{2} \mathrm{~s}^{-1}$ at $50 \mathrm{~m}$, above which it was assumed constant. The sensitivity of the model to this coefficient is discussed later.

The model was constrained with the diurnal time-varying concentrations of isoprene and $\mathrm{OH}$, obtained by averaging the measurements for each of the two campaigns. The values were read into the model at 20 model-minute intervals. The 
Campaign 1

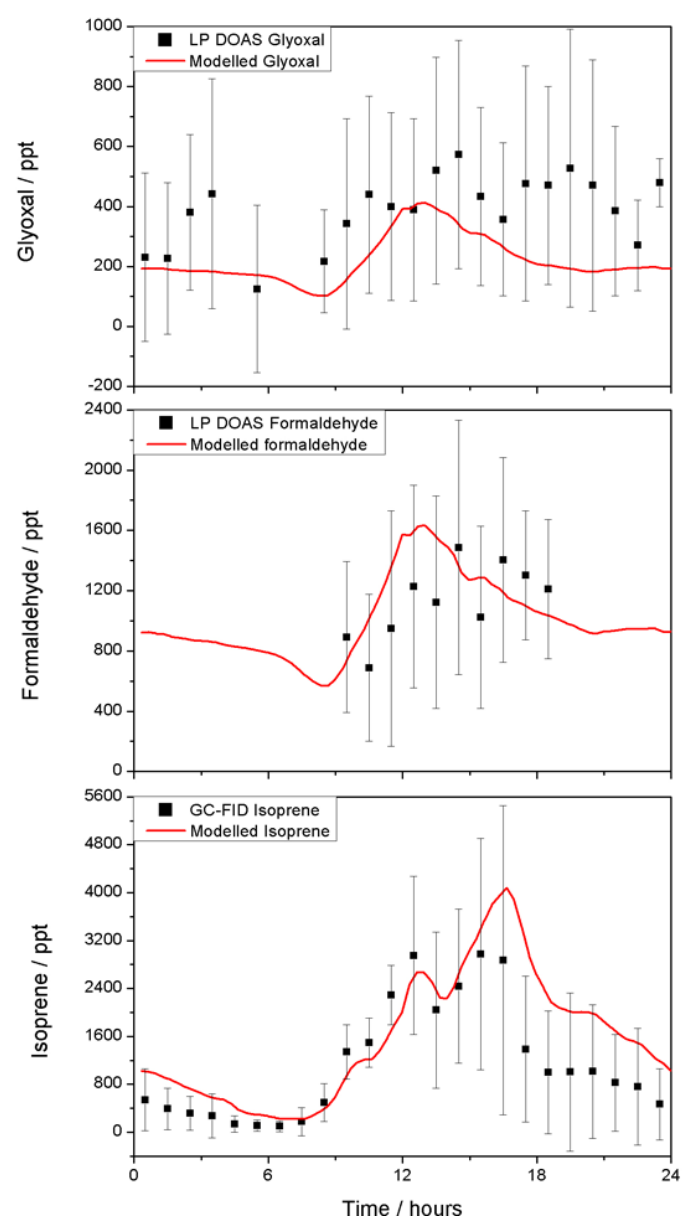

Campaign 2

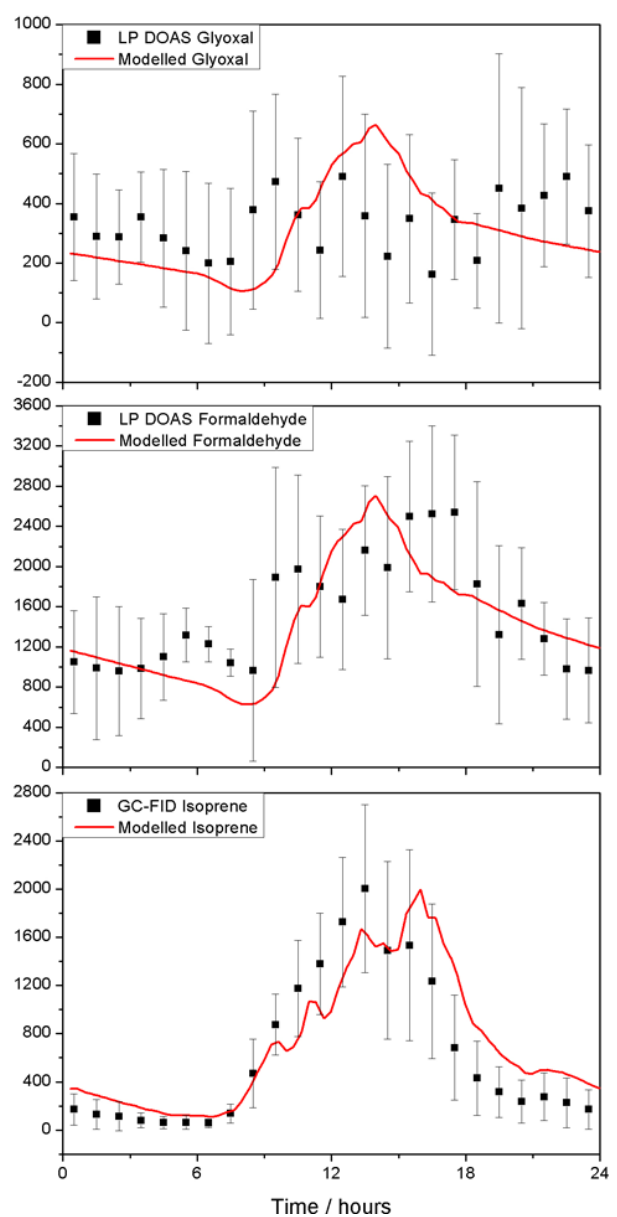

Fig. 10. Average diurnal profiles for glyoxal and formaldehyde measured by LP-DOAS, and isoprene measured by GC-FID, for campaigns 1 and 2 . The black squares show the measured average and associated $1 \sigma$ standard deviation, the red lines show the modelled glyoxal and formaldehyde averaged over the first $180 \mathrm{~m}$ and the modelled isoprene at $185 \mathrm{~m}$.

isoprene measurements were input into the lowest level of the model representing the top of the forest canopy - the height at which the LP-DOAS retro-reflector was placed. There are several factors to consider which arise from the difference in height between the LP-DOAS, MAX-DOAS and the complementary measurements of $\mathrm{OH}$ and isoprene. First, the glyoxal and formaldehyde concentrations represent a spatial average over the $3.4 \mathrm{~km}$ path between the LP-DOAS and retroreflector array. Second, the light path was not horizontal over the forest canopy, but at an angle of $3^{\circ}$ producing a vertical displacement of $180 \mathrm{~m}$ between the retro-reflector array and the LP-DOAS (Fig. 2). Third, the canopy itself was not flat and the trees continued up the side of the hill at Bukit Atur. The isoprene measurements used for the diurnal profile in the model were recorded at $5 \mathrm{~m}$ on the FAGE container, which was positioned in a clearing on top of the hill at Bukit Atur above the tree height, and were therefore assumed to be at $185 \mathrm{~m}$ above the canopy in the model. That is, significant oxidation by $\mathrm{OH}$ would already have occurred between the canopy and the point of measurement. This situation was dealt with in the model by multiplying the measured isoprene diurnal profile by a factor and inputting the resulting concentration of isoprene in the lowest box (i.e., just above the canopy). The factor was chosen so that the peak isoprene concentration modelled at $185 \mathrm{~m}$ matched that of the observations; this factor was 2.3 for the first campaign and 3.0 for the second campaign. For comparison of the formaldehyde and glyoxal model output with the LP-DOAS measurements, an average of the model results over the first $180 \mathrm{~m}$ was taken. In the absence of profile measurements, the $\mathrm{OH}$ measurements were input into every model level so that the $\mathrm{OH}$ remained constant with height.

The production of glyoxal and formaldehyde was assumed to be solely from oxidation of isoprene for the reasons mentioned above. In the simplified chemistry scheme, glyoxal and formaldehyde were treated as direct products. The branching ratio for glyoxal production from the isoprene $+\mathrm{OH}$ reaction was initially taken as $8 \%$, consistent 
with the Master Chemical Mechanism version 3.2 (Jenkin et al., 1997; Saunders et al., 2003), and a $31.5 \%$ branching ratio for formaldehyde production was assumed (Jenkin et al., 1998) (estimates of the branching ratio for formaldehyde vary between 31.5 and $34.0 \%$ ). According to Jenkin et al. (1998), under high $\mathrm{NO}_{\mathrm{x}}$ conditions $\left(9 \mathrm{ppb} \mathrm{NO} \mathrm{x}_{\mathrm{x}}\right)$ the formaldehyde yield more than doubles to $65.6 \%$ compared to the yield in the absence of $\mathrm{NO}_{\mathrm{x}}(31.5 \%)$. Considering the daily maximum $\mathrm{NO}_{\mathrm{x}}$ during $\mathrm{OP} 3$ was typically around $300 \mathrm{ppt}$, this would have little effect on the formaldehyde yield and therefore the yield in the absence of $\mathrm{NO}_{\mathrm{x}}$ was used. However, it should be noted that the experimental conditions of Jenkin et al. (1998) featured high $\mathrm{RO}_{2} / \mathrm{HO}_{2}$ ratios which would favour production of formaldehyde and these high ratios may not be applicable to ambient low $\mathrm{NO}_{\mathrm{x}}$ environments. Stavrakou et al. (2009) found that the yield of glyoxal from isoprene oxidation by $\mathrm{OH}$ increased only slightly, from $8.4 \%$ to $9.9 \%$, when moving from low to high $\mathrm{NO}_{\mathrm{x}}$ conditions. Therefore the yield of $8 \%$ chosen here appears reasonable for low $\mathrm{NO}_{\mathrm{x}}$ conditions. Sensitivity studies using the MCM chemical scheme found that a doubling of the observed $\mathrm{NO}_{\mathrm{x}}$ produced a $30 \%$ increase in the concentrations of $\mathrm{HCHO}$ and $\mathrm{CHOCHO}$.

The loss processes for both species were oxidation by $\mathrm{OH}$ and photolysis; photolysis rates were calculated on-line using an explicit two-stream radiation scheme from Thompson (1984) and absorption cross-section data for HCHO and CHOCHO (Meller and Moortgat, 2000; Volkamer et al., 2005b). Uptake on to aqueous aerosol was also included for glyoxal, using an uptake coefficient $\gamma=2.9 \times 10^{-3}$ (Liggio et al., 2005) and an aerosol volumetric surface area of $5 \times 10^{-7} \mathrm{~cm}^{2} \mathrm{~cm}^{-3}$ based on measurements performed during the campaigns (Whitehead et al., 2010). An additional source of formaldehyde is the photolysis of glyoxal, however the branching ratio of this pathway is only $2.9 \%$ (Tadic et al., 2006).

The two campaigns were modelled separately due to the large differences in the average diurnal profile for both isoprene and $\mathrm{OH}$, with around $50 \%$ more isoprene observed during the first campaign, and around double the amount of $\mathrm{OH}$ in the second campaign compared to the first. The sensitivity of the modelled $\mathrm{HCHO}$ and $\mathrm{CHOCHO}$ to a number of model parameters are discussed below.

\subsection{Height dependence of HCHO and CHOCHO}

Figure 10 compares the modelled diurnal profiles of glyoxal, formaldehyde and isoprene with the measurements made by the LP-DOAS and on the GAW tower, averaged for each of the campaigns. There is good agreement, within the $1 \sigma$ standard deviations of the measured averages, for all three species. Figure 11 shows the modelled diurnal variations of the vertical profiles of these species above the canopy. Note that most of the glyoxal is predicted to reside less than $250 \mathrm{~m}$ above the canopy, which makes the SCIAMACHY vertical column abundances (Vrekoussis et al., 2009) closer to $1 \mathrm{ppb}$, in even better agreement with the present LP-DOAS results. The formaldehyde also mostly resides below $250 \mathrm{~m}$, which validates the assumption used in Fig. 8 to compare the MAXDOAS slant column at $2^{\circ}$ elevation angle with the LP-DOAS.

\subsection{Effect of vertical mixing}

Another important parameter in the model is the eddy diffusion coefficient, $K_{z}$. To test the model sensitivity, the $K_{z}$ profile was doubled and model runs carried out for each campaign using the initial conditions as before. The modelled isoprene at $185 \mathrm{~m}$ showed a maximum increase of $35 \%$ at midday. The glyoxal and formaldehyde over the first $180 \mathrm{~m}$ showed an average decrease of 11 and $13 \%$, respectively, for both campaigns, with the maximum difference observed at sunrise (Fig. 12). Thus, the sensitivity to $K_{z}$ appears to be modest. However, although convection is not treated explicitly in the model, it is likely to increase the vertical and horizontal inhomogeneity of the chemistry in this environment.

\subsection{The HCHO/CHOCHO ratio}

The modelled ratio of glyoxal to formaldehyde can be compared with the measured ratio, in order to investigate the branching ratio for the isoprene $+\mathrm{OH}$ reaction to yield glyoxal. The average glyoxal and formaldehyde over the first $180 \mathrm{~m}$ in the model was computed to compare with the LPDOAS measurements. Various estimates between 3 and $10 \%$ have been proposed for the glyoxal branching ratio based on chamber studies and modelling work (Fu et al., 2008; Volkamer et al., 2007; Stavrakou et al., 2009). The model was therefore initiated using branching ratios over this range, keeping the formaldehyde branching ratio at $31.5 \%$. Figure 13 compares the resulting glyoxal/formaldehyde ratio with that obtained from the LP-DOAS measurements, where the ratio of the average glyoxal to the average formaldehyde concentration using the hourly data in Fig. 10 was used. Note that due to the limited spectral range of the DOAS, the glyoxal and formaldehyde measurements are not concurrent and therefore it was not possible to calculate a direct, nonaveraged glyoxal/formaldehyde ratio. Only daytime values were considered because the isoprene oxidation by $\mathrm{OH}$ is a daytime source for both species.

Figure 13 shows that while the LP-DOAS measured ratios do not, within the measurement uncertainty, exclude the branching ratio being anywhere within the range $3-10 \%$, the agreement is much improved if the ratio lies between 6 and $10 \%$ for campaign 2 , and the best agreement is found using $8 \%$ - which is consistent with the Master Chemical Mechanism version 3.1 (Jenkin et al., 1997; Saunders et al., 2003) and also more recent studies by Galloway et al. (2011a) who found the ratio to lie between 8 and $11 \%$. The apparently higher ratios observed for campaign 1 (though there is still agreement within error) may point to additional organic 

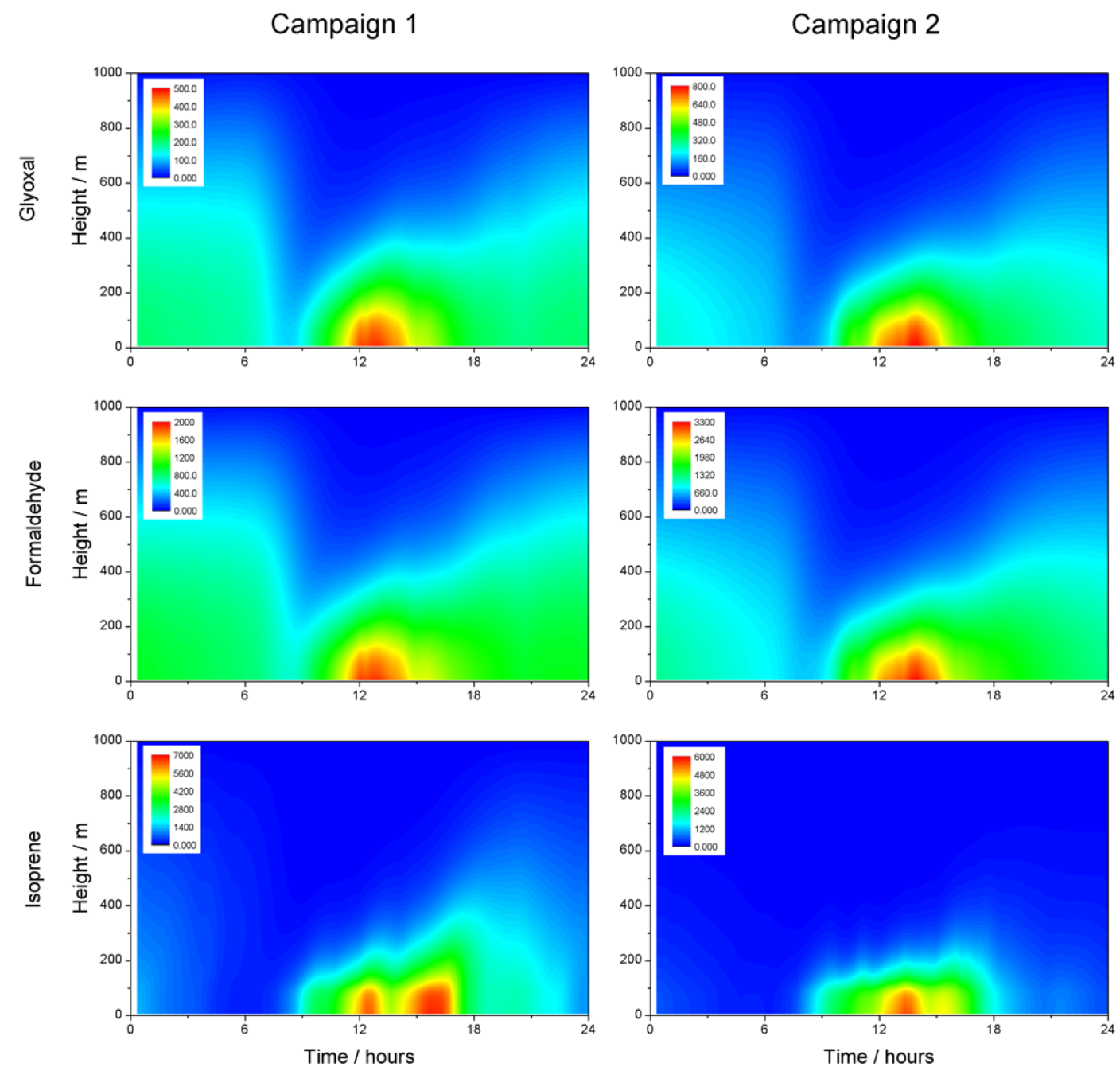

Fig. 11. Diurnal variations of the vertical profiles of glyoxal, formaldehyde and isoprene in the boundary layer, using a branching ratio of $8 \%$ for the glyoxal yield from isoprene $+\mathrm{OH}$.

species as sources of glyoxal above the forest canopy. These ratios are significantly higher than observed using satellite observations (Vrekoussis et al., 2010) where ratios of 0.06 are proposed for areas with high biogenic VOC emissions. however, this may be indicative of the reduced sensitivity of the satellite measurements to the lower boundary layer and the very high $\mathrm{HO}_{\mathrm{x}}$ turnover in this environment.

\subsection{Effect of $\mathrm{OH}$}

Another important parameter in the model is the measured $\mathrm{OH}$. The $\mathrm{OH}$ concentrations measured during both OP3 campaigns were significantly higher than would be predicted for a forest environment, where the abundance of organic species (sinks for $\mathrm{OH}$ ) should lead to a low concentration above the canopy. Indeed, by using the measured $\mathrm{OH}$ reactivity during the campaign and production from all measured $\mathrm{OH}$ sources in a zero-dimensional model, Whalley et al. (2011) predicted an $\mathrm{OH}$ concentration an order of magnitude smaller than the value typically observed at noon (e.g., $2.5 \times 10^{6} \mathrm{~cm}^{-3}$ in the first campaign). They were able to match the observed $\mathrm{OH}$ by including an $\mathrm{HO}_{2}$ recycling mechanism. Figure 14 shows the modelled glyoxal using the $\mathrm{OH}$ concentrations measured by FAGE and using an order of magnitude lower $\mathrm{OH}$, clearly showing that the measured glyoxal cannot be explained using the lower $\mathrm{OH}$ values. In the present model, a lower limit to the daytime $\mathrm{OH}$ concentration can be obtained by using the upper limit to the branching ratio for glyoxal production from isoprene oxidation of $10 \%$ (Stavrakou et al., 2009). This shows that the lower limit to the $\mathrm{OH}$ concentration is only a factor of 2 less than the observations. In fact, the branching ratio for glyoxal formation from $\mathrm{OH}+$ isoprene would need to be $\sim 40 \%$ if the $\mathrm{OH}$ concentrations really were an order of magnitude lower. 


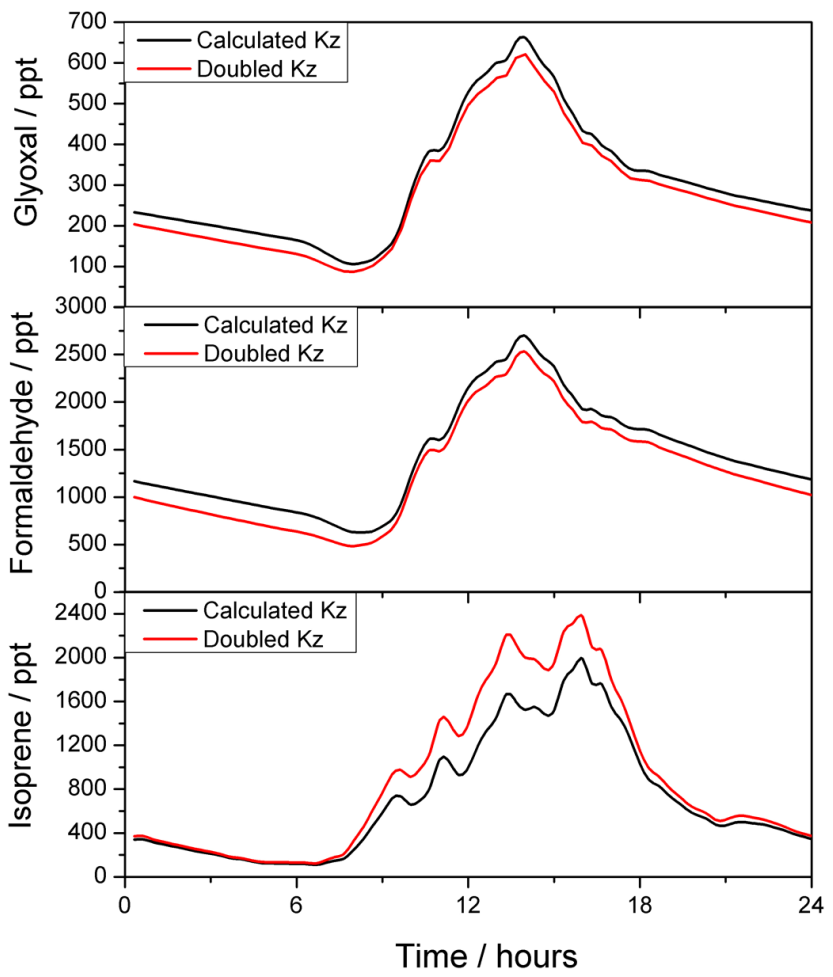

Fig. 12. Modelled diurnal profiles for glyoxal, formaldehyde and isoprene using the estimated $K_{z}$ profile (black line, see text for details) and double that value (red line).

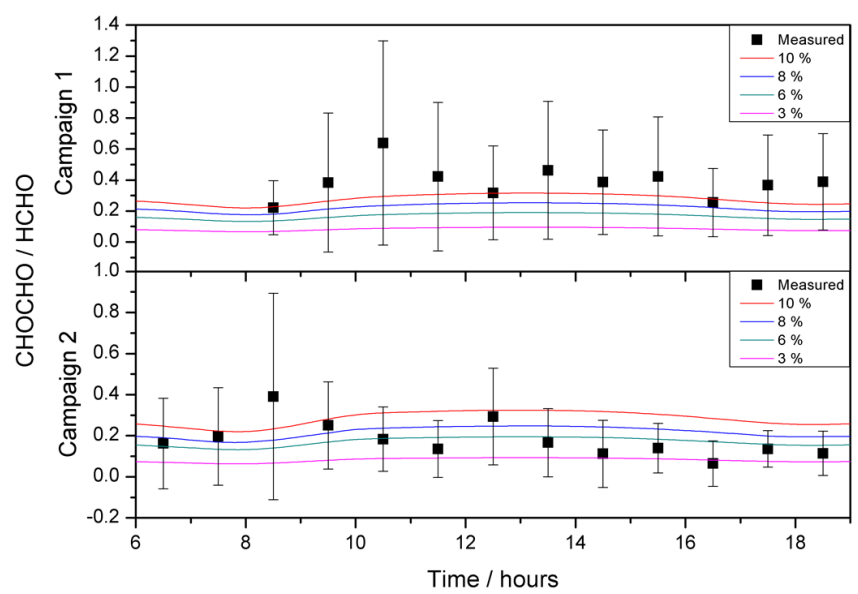

Fig. 13. The glyoxal/formaldehyde ratio between 06:00 and 19:00 LT from the LP-DOAS measurements (black) and from the model using branching ratios for the yield of glyoxal from the $\mathrm{OH}+$ isoprene reaction of $3,6,8$ and $10 \%$, for each of the OP3 campaigns.

\subsection{Uptake on aerosol}

As discussed in the Introduction, there have been numerous studies into the role of glyoxal in secondary organic aerosol formation, so the sensitivity of the glyoxal measurements

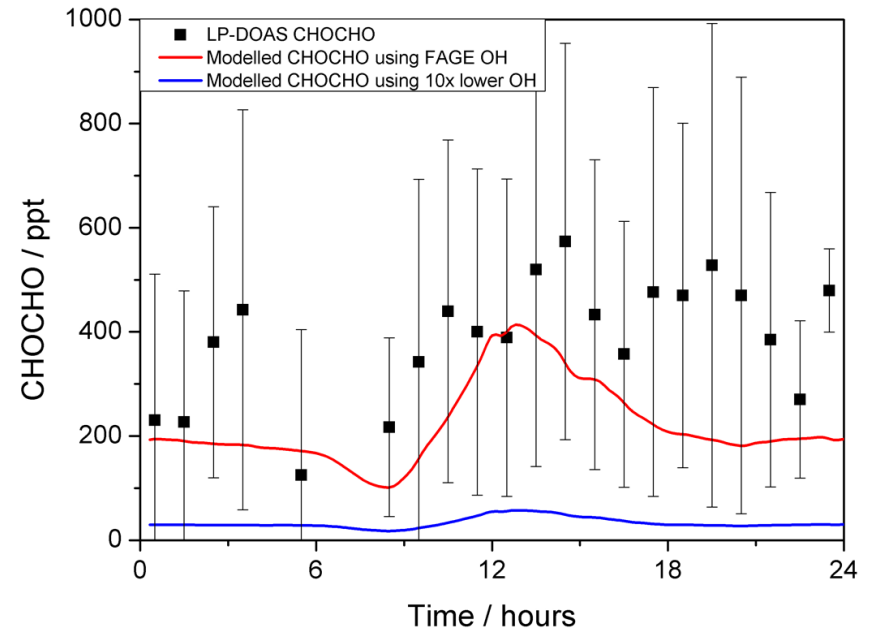

Fig. 14. Measured (black squares) and modelled CHOCHO using FAGE OH measurements (red line) and using an order of magnitude lower $\mathrm{OH}$ (blue line) for campaign 1.

to uptake onto aerosol was investigated. The uptake of glyoxal on background aerosol was not found to be a significant loss process. This is due to the low uptake coefficient, $\gamma=2.9 \times 10^{-3}$ (Liggio et al., 2005), and the small aerosol volumetric surface area (average $=5 \times 10^{-7} \mathrm{~cm}^{2} \mathrm{~cm}^{-3}$, Hewitt et al., 2010). An increase in the aerosol volumetric surface area by a factor of 3 (i.e., to the maximum observed during the campaigns) decreases the lifetime with respect to uptake to about $7 \mathrm{~h}$, but this only reduces the glyoxal concentration at midday by $\sim 5 \%$ because it does not compete effectively with photolysis and reaction with $\mathrm{OH}$. In addition, the presence of appreciable levels of glyoxal at night is further evidence that uptake onto aerosol is not a significant loss process.

Another factor to consider is that glyoxal is not particularly soluble. For example, taking an average measured night-time glyoxal concentration of $500 \mathrm{ppt}$ together with the Henry's law coefficient of $4.2 \times 10^{5} \mathrm{M} \mathrm{atm}^{-1}$ (Ip et al., 2009), the saturation concentration of glyoxal in the aerosol is $2.1 \times 10^{-4} \mathrm{M}$. Using an average aerosol diameter of $100 \mathrm{~nm}$ and the glyoxal uptake coefficient above, glyoxal will equilibrate with the aerosol in less than $1 \mathrm{~s}$. Therefore uptake onto aerosol does not represent a significant loss process for glyoxal from the gas phase in this environment; however, because glyoxal reaches saturation within aerosol rapidly it could play an important role in aerosol growth.

\section{Conclusions}

The measurements of glyoxal and formaldehyde reported here demonstrate significant photochemistry occurring above the tropical rainforest of Borneo and add to the wealth of data obtained from the 2008 OP3 campaign. The results show that 
glyoxal is far more abundant above the forest canopy than in other rural environments as reported in previous studies. Modelling studies have shown that the high concentrations of glyoxal observed can be explained by oxidation of isoprene by $\mathrm{OH}$ using current estimates of the branching ratio for this pathway, within experimental error. The measurements of formaldehyde are also consistent with isoprene as its main source above the forest canopy. The lifetimes of glyoxal and formaldehyde were found to be determined by photolysis and reaction with $\mathrm{OH}$; uptake onto aerosol only played a minor role in gas-phase glyoxal loss. The glyoxal/formaldehyde ratio in this environment, which averages around 0.2 , is reproduced in the model using current estimates of the branching ratios from isoprene oxidation for both species. Finally, the observed glyoxal mixing ratios could only be reproduced in the model using the measured $\mathrm{OH}$ concentrations, providing further evidence that the unusually high $\mathrm{OH}$ concentrations observed above the forest canopy were not an artefact of the measurement technique.

Acknowledgements. This work was supported by the UK Natural Environment Research Council grant NE/D002060/1, and a NERC research studentship to SMM.

This is paper number 517 of the Royal Society's South East Asian Rainforest Research Programme.

Edited by: A. B. Guenther

\section{References}

Arlander, D. W., Bruning, D., Schmidt, U., and Ehhalt, D. H.: The tropospheric distribution of formaldehyde during tropoz-ii, J. Atmos. Chem., 22, 251-269, 1995.

Bogumil, K., Orphal, J., Homann, T., Voigt, S., Spietz, P., Fleischmann, O. C., Vogel, A., Hartmann, M., Kromminga, H., Bovensmann, H., Frerick, J., and Burrows, J. P.: Measurements of molecular absorption spectra with the sciamachy pre-flight model: Instrument characterization and reference data for atmospheric remote-sensing in the $230-2380 \mathrm{~nm}$ region, J. Photochem. Photobiol. A-Chem., 157, 167-184, doi:10.1016/s10106030(03)00062-5, 2003.

Burrows, J. P., Richter, A., Dehn, A., Deters, B., Himmelmann, S., and Orphal, J.: Atmospheric remote-sensing reference data from gome - 2. Temperature-dependent absorption cross sections of $\mathrm{O}_{3}$ in the 231-794 nm range, J. Quant. Spectrosc. Ra., 61, 509517, 1999.

Cardenas, L. M., Brassington, D. J., Allan, B. J., Coe, H., Alicke, B., Platt, U., Wilson, K. M., Plane, J. M. C., and Penkett, S. A.: Intercomparison of formaldehyde measurements in clean and polluted atmospheres, J. Atmos. Chem., 37, 53-80, 2000.

Choi, W., Faloona, I. C., Bouvier-Brown, N. C., McKay, M., Goldstein, A. H., Mao, J., Brune, W. H., LaFranchi, B. W., Cohen, R. C., Wolfe, G. M., Thornton, J. A., Sonnenfroh, D. M., and Millet, D. B.: Observations of elevated formaldehyde over a forest canopy suggest missing sources from rapid oxidation of arboreal hydrocarbons, Atmos. Chem. Phys., 10, 8761-8781, doi:10.5194/acp-10-8761-2010, 2010.

Corrigan, A. L., Hanley, S. W., and Haan, D. O.: Uptake of glyoxal by organic and inorganic aerosol, Environ. Sci. Technol., 42, 4428-4433, doi:10.1021/es7032394, 2008.

Dufour, G., Wittrock, F., Camredon, M., Beekmann, M., Richter, A., Aumont, B., and Burrows, J. P.: SCIAMACHY formaldehyde observations: constraint for isoprene emission estimates over Europe?, Atmos. Chem. Phys., 9, 1647-1664, doi:10.5194/acp-91647-2009, 2009.

Fu, T. M., Jacob, D. J., Wittrock, F., Burrows, J. P., Vrekoussis, M., and Henze, D. K.: Global budgets of atmospheric glyoxal and methylglyoxal, and implications for formation of secondary organic aerosols, J. Geophys. Res.-Atmos., 113, D15303, doi:10.1029/2007jd009505, 2008.

Galloway, M. M., Huisman, A. J., Yee, L. D., Chan, A. W. H., Loza, C. L., Seinfeld, J. H., and Keutsch, F. N.: Yields of oxidized volatile organic compounds during the $\mathrm{OH}$ radical initiated oxidation of isoprene, methyl vinyl ketone, and methacrolein under high-NO $\mathrm{NO}_{\mathrm{x}}$ conditions, Atmos. Chem. Phys., 11, 10779-10790, doi:10.5194/acp-11-10779-2011, 2011a.

Galloway, M. M., Loza, C. L., Chhabra, P. S., Chan, A. W. H., Yee, L. D., Seinfeld, J. H., and Keutsch, F. N.: Analysis of photochemical and dark glyoxal uptake: Implications for soa formation, Geophys. Res. Lett., 38, L17811, doi:10.1029/2011gl048514, $2011 b$.

Greenblatt, G. D., Orlando, J. J., Burkholder, J. B., and Ravishankara, A. R.: Absorption-measurements of oxygen between $330 \mathrm{~nm}$ and $1140 \mathrm{~nm}$, J. Geophys. Res.-Atmos., 95, 1857718582, doi:10.1029/JD095iD11p18577, 1990.

Grosjean, D.: Ambient levels of formaldehyde, acetaldehyde, and formic-acid in southern california - results of a one-year baseline study, Environ. Sci. Technol., 25, 710-715, 1991.

Grosjean, D., Miguel, A. H., and Tavares, T. M.: Urban air-pollution in brazil - acetaldehyde and other carbonyls, Atmos. Environ. BUrb., 24, 101-106, 1990.

Guenther, A., Hewitt, C. N., Erickson, D., Fall, R., Geron, C., Graedel, T., Harley, P., Klinger, L., Lerdau, M., McKay, W. A., Pierce, T., Scholes, B., Steinbrecher, R., Tallamraju, R., Taylor, J., and Zimmerman, P.: A global-model of natural volatile organic-compound emissions, J. Geophys. Res.-Atmos., 100, 8873-8892, 1995.

Hak, C., Pundt, I., Trick, S., Kern, C., Platt, U., Dommen, J., Ordóñez, C., Prévôt, A. S. H., Junkermann, W., Astorga-Lloréns, C., Larsen, B. R., Mellqvist, J., Strandberg, A., Yu, Y., Galle, B., Kleffmann, J., Lörzer, J. C., Braathen, G. O., and Volkamer, R.: Intercomparison of four different in-situ techniques for ambient formaldehyde measurements in urban air, Atmos. Chem. Phys., 5, 2881-2900, doi:10.5194/acp-5-2881-2005, 2005.

Heald, C. L., Jacob, D. J., Park, R. J., Russell, L. M., Huebert, B. J., Seinfeld, J. H., Liao, H., and Weber, R. J.: A large organic aerosol source in the free troposphere missing from current models, Geophys. Res. Lett., 32, L18809, doi:10.1029/2005g1023831, 2005.

Heikes, B. G.: Formaldehyde and hydroperoxides at mauna-loa observatory, J. Geophys. Res.-Atmos., 97, 18001-18013, 1992.

Hewitt, C. N., Lee, J. D., MacKenzie, A. R., Barkley, M. P., Carslaw, N., Carver, G. D., Chappell, N. A., Coe, H., Collier, C., Commane, R., Davies, F., Davison, B., DiCarlo, P., Di Marco, C. F., Dorsey, J. R., Edwards, P. M., Evans, M. J., Fowler, D., Furneaux, 
K. L., Gallagher, M., Guenther, A., Heard, D. E., Helfter, C., Hopkins, J., Ingham, T., Irwin, M., Jones, C., Karunaharan, A., Langford, B., Lewis, A. C., Lim, S. F., MacDonald, S. M., Mahajan, A. S., Malpass, S., McFiggans, G., Mills, G., Misztal, P., Moller, S., Monks, P. S., Nemitz, E., Nicolas-Perea, V., Oetjen, H., Oram, D. E., Palmer, P. I., Phillips, G. J., Pike, R., Plane, J. M. C., Pugh, T., Pyle, J. A., Reeves, C. E., Robinson, N. H., Stewart, D., Stone, D., Whalley, L. K., and Yin, X.: Overview: oxidant and particle photochemical processes above a south-east Asian tropical rainforest (the OP3 project): introduction, rationale, location characteristics and tools, Atmos. Chem. Phys., 10, 169-199, doi:10.5194/acp-10-169-2010, 2010.

Hopkins, J. R., Lewis, A. C., and Read, K. A.: A two-column method for long-term monitoring of non-methane hydrocarbons (nmhcs) and oxygenated volatile organic compounds (o-vocs), J. Environ. Monit., 5, 8-13, doi:10.1039/b202798d, 2003.

Huisman, A. J., Hottle, J. R., Galloway, M. M., DiGangi, J. P., Coens, K. L., Choi, W., Faloona, I. C., Gilman, J. B., Kuster, W. C., de Gouw, J., Bouvier-Brown, N. C., Goldstein, A. H., LaFranchi, B. W., Cohen, R. C., Wolfe, G. M., Thornton, J. A., Docherty, K. S., Farmer, D. K., Cubison, M. J., Jimenez, J. L., Mao, J., Brune, W. H., and Keutsch, F. N.: Photochemical modeling of glyoxal at a rural site: observations and analysis from BEARPEX 2007, Atmos. Chem. Phys., 11, 8883-8897, doi:10.5194/acp-11-88832011, 2011.

Ip, H. S. S., Huang, X. H. H., and Yu, J. Z.: Effective henry's law constants of glyoxal, glyoxylic acid, and glycolic acid, Geophys. Res. Lett., 36, L01802, doi:10.1029/2008g1036212, 2009.

Jacobson, M. Z.: Fundamentals of atmospheric modeling, 2nd Edn., Cambridge University Press, New York, 2005.

Jayne, J. T., Worsnop, D. R., Kolb, C. E., Swartz, E., and Davidovits, P.: Uptake of gas-phase formaldehyde by aqueous acid surfaces, J. Phys. Chem., 100, 8015-8022, 1996.

Jenkin, M. E., Saunders, S. M., Derwent, R. G., and Pilling, M. J.: Construction and application of a master chemical mechanism $(\mathrm{mcm})$ for modelling tropospheric chemistry, Abstr. Pap. Am. Chem. Soc., 214, 116-COLL, 1997.

Jenkin, M. E., Boyd, A. A., and Lesclaux, R.: Peroxy radical kinetics resulting from the oh-initiated oxidation of 1,3-butadiene, 2,3-dimethyl-1,3-butadiene and isoprene, J. Atmos. Chem., 29, 267-298, doi:10.1023/a:1005940332441, 1998.

Jones, C. E., Hopkins, J. R., and Lewis, A. C.: In situ measurements of isoprene and monoterpenes within a south-east Asian tropical rainforest, Atmos. Chem. Phys., 11, 6971-6984, doi:10.5194/acp-11-6971-2011, 2011

Kroll, J. H., Ng, N. L., Murphy, S. M., Varutbangkul, V., Flagan, R. C., and Seinfeld, J. H.: Chamber studies of secondary organic aerosol growth by reactive uptake of simple carbonyl compounds, J. Geophys. Res.-Atmos., 110, D23207, doi:10.1029/2005jd006004, 2005.

Langford, B., Davison, B., Nemitz, E., and Hewitt, C. N.: Mixing ratios and eddy covariance flux measurements of volatile organic compounds from an urban canopy (Manchester, UK), Atmos. Chem. Phys., 9, 1971-1987, doi:10.5194/acp-9-1971-2009, 2009.

Lee, Y. N., Zhou, X., Kleinman, L. I., Nunnermacker, L. J., Springston, S. R., Daum, P. H., Newman, L., Keigley, W. G., Holdren, M. W., Spicer, C. W., Young, V., Fu, B., Parrish, D. D., Holloway, J., Williams, J., Roberts, J. M., Ryerson, T. B., and Fehsenfeld, F. C.: Atmospheric chemistry and distribution of formaldehyde and several multioxygenated carbonyl compounds during the 1995 nashville middle tennessee ozone study, J. Geophys. Res.-Atmos., 103, 22449-22462, 1998.

Lerot, C., Stavrakou, T., De Smedt, I., Müller, J.-F., and Van Roozendael, M.: Glyoxal vertical columns from GOME-2 backscattered light measurements and comparisons with a global model, Atmos. Chem. Phys., 10, 12059-12072, doi:10.5194/acp10-12059-2010, 2010.

Liggio, J., Li, S. M., and McLaren, R.: Reactive uptake of glyoxal by particulate matter, J. Geophys. Res.-Atmos., 110, D10304, doi:10.1029/2004jd005113, 2005.

Lowe, D. C. and Schmidt, U.: Formaldehyde (hcho) measurements in the nonurban atmosphere, J. Geophys. Res.-Oc. Atm., 88, 844-858, 1983.

Meller, R. and Moortgat, G. K.: Temperature dependence of the absorption cross sections of formaldehyde between 223 and $323 \mathrm{k}$ in the wavelength range $225-375 \mathrm{~nm}$, J. Geophys. Res.-Atmos., 105, 7089-7101, 2000.

Munger, J. W., Jacob, D. J., Daube, B. C., Horowitz, L. W., Keene, W. C., and Heikes, B. G.: Formaldehyde, glyoxal, and methylglyoxal in air and cloudwater at a rural mountain site in central virginia, J. Geophys. Res.-Atmos., 100, 9325-9333, 1995.

Myriokefalitakis, S., Vrekoussis, M., Tsigaridis, K., Wittrock, F., Richter, A., Brühl, C., Volkamer, R., Burrows, J. P., and Kanakidou, M.: The influence of natural and anthropogenic secondary sources on the glyoxal global distribution, Atmos. Chem. Phys., 8, 4965-4981, doi:10.5194/acp-8-4965-2008, 2008.

Pearson, G., Davies, F., and Collier, C.: Remote sensing of the tropical rain forest boundary layer using pulsed Doppler lidar, Atmos. Chem. Phys., 10, 5891-5901, doi:10.5194/acp-10-58912010, 2010.

Plane, J. M. C. and Saiz-Lopez, A.: Analytical techniques for atmospheric measurement, edited by: Heard, D. E., Blackwell, Oxford, 2006.

Platt, U. and Stutz, J.: Differential optical absorption spectroscopy, Physics of earth and space environments, Springer-Verlag, Heidelberg, 2008.

Possanzini, M., Di Palo, V., and Cecinato, A.: Sources and photodecomposition of formaldehyde and acetaldehyde in rome ambient air, Atmos. Environ., 36, 3195-3201, 2002.

Rothman, L. S., Barbe, A., Benner, D. C., Brown, L. R., CamyPeyret, C., Carleer, M. R., Chance, K., Clerbaux, C., Dana, V., Devi, V. M., Fayt, A., Flaud, J. M., Gamache, R. R., Goldman, A., Jacquemart, D., Jucks, K. W., Lafferty, W. J., Mandin, J. Y., Massie, S. T., Nemtchinov, V., Newnham, D. A., Perrin, A., Rinsland, C. P., Schroeder, J., Smith, K. M., Smith, M. A. H., Tang, K., Toth, R. A., Vander Auwera, J., Varanasi, P., and Yoshino, K.: The hitran molecular spectroscopic database: Edition of 2000 including updates through 2001, J. Quant. Spectrosc. Ra., 82, 5-44, doi:10.1016/s0022-4073(03)00146-8, 2003.

Saiz-Lopez, A., Plane, J. M. C., Mahajan, A. S., Anderson, P. S., Bauguitte, S. J.-B., Jones, A. E., Roscoe, H. K., Salmon, R. A., Bloss, W. J., Lee, J. D., and Heard, D. E.: On the vertical distribution of boundary layer halogens over coastal Antarctica: implications for $\mathrm{O}_{3}, \mathrm{HO}_{\mathrm{x}}, \mathrm{NO}_{\mathrm{x}}$ and the $\mathrm{Hg}$ lifetime, Atmos. Chem. Phys., 8, 887-900, doi:10.5194/acp-8-887-2008, 2008.

Saunders, S. M., Jenkin, M. E., Derwent, R. G., and Pilling, M. J.: Protocol for the development of the Master Chemical 
Mechanism, MCM v3 (Part A): tropospheric degradation of nonaromatic volatile organic compounds, Atmos. Chem. Phys., 3, 161-180, doi:10.5194/acp-3-161-2003, 2003.

Sinreich, R., Volkamer, R., Filsinger, F., Frieß, U., Kern, C., Platt, U., Sebastián, O., and Wagner, T.: MAX-DOAS detection of glyoxal during ICARTT 2004, Atmos. Chem. Phys., 7, 1293-1303, doi:10.5194/acp-7-1293-2007, 2007.

Sinreich, R., Coburn, S., Dix, B., and Volkamer, R.: Ship-based detection of glyoxal over the remote tropical Pacific Ocean, Atmos. Chem. Phys., 10, 11359-11371, doi:10.5194/acp-1011359-2010, 2010.

Spaulding, R. S., Schade, G. W., Goldstein, A. H., and Charles, M. J.: Characterization of secondary atmospheric photooxidation products: Evidence for biogenic and anthropogenic sources, J. Geophys. Res.-Atmos., 108, 4247, doi:10.1029/2002jd002478, 2003.

Stavrakou, T., Müller, J.-F., De Smedt, I., Van Roozendael, M., Kanakidou, M., Vrekoussis, M., Wittrock, F., Richter, A., and Burrows, J. P.: The continental source of glyoxal estimated by the synergistic use of spaceborne measurements and inverse modelling, Atmos. Chem. Phys., 9, 8431-8446, doi:10.5194/acp-98431-2009, 2009.

Stickler, A., Fischer, H., Bozem, H., Gurk, C., Schiller, C., Martinez-Harder, M., Kubistin, D., Harder, H., Williams, J., Eerdekens, G., Yassaa, N., Ganzeveld, L., Sander, R., and Lelieveld, J.: Chemistry, transport and dry deposition of trace gases in the boundary layer over the tropical Atlantic Ocean and the Guyanas during the GABRIEL field campaign, Atmos. Chem. Phys., 7, 3933-3956, doi:10.5194/acp-7-3933-2007, 2007.

Tadic, J., Moortgat, G. K., and Wirtz, K.: Photolysis of glyoxal in air, J. Photochem. Photobiol. A-Chem., 177, 116-124, doi:10.1016/j.jphotochem.2005.10.010, 2006.

Tan, Y., Perri, M. J., Seitzinger, S. P., and Turpin, B. J.: Effects of precursor concentration and acidic sulfate in aqueous glyoxal-oh radical oxidation and implications for secondary organic aerosol, Environ. Sci. Technol., 43, 8105-8112, doi:10.1021/es901742f, 2009.

Thompson, A. M.: The effect of clouds on photolysis rates and ozone formation in the unpolluted troposphere, J. Geophys. Res.Atmos., 89, 1341-1349, doi:10.1029/JD089iD01p01341, 1984.

Vandaele, A. C., Hermans, C., Simon, P. C., Carleer, M., Colin, R., Fally, S., Merienne, M. F., Jenouvrier, A., and Coquart, B.: Measurements of the $\mathrm{NO}_{2}$ absorption cross-section from $42000 \mathrm{~cm}^{-1}$ to $10000 \mathrm{~cm}^{-1}(238-1000 \mathrm{~nm})$ at $220 \mathrm{k}$ and $294 \mathrm{k}$, J. Quant. Spectrosc. Ra., 59, 171-184, 1998.

Volkamer, R., Platt, U., and Wirtz, K.: Primary and secondary glyoxal formation from aromatics: Experimental evidence for the bicycloalkyl-radical pathway from benzene, toluene, and pxylene, J. Phys. Chem. A, 105, 7865-7874, 2001.

Volkamer, R., Molina, L. T., Molina, M. J., Shirley, T., and Brune, W. H.: Doas measurement of glyoxal as an indicator for fast voc chemistry in urban air, Geophys. Res. Lett., 32, L08806, doi:10.1029/2005g1022616, 2005a.
Volkamer, R., Spietz, P., Burrows, J., and Platt, U.: High-resolution absorption cross-section of glyoxal in the uv-vis and ir spectral ranges, J. Photochem. Photobiol. A-Chem., 172, 35-46, 2005 b.

Volkamer, R., Martini, F. S., Molina, L. T., Salcedo, D., Jimenez, J. L., and Molina, M. J.: A missing sink for gas-phase glyoxal in mexico city: Formation of secondary organic aerosol, Geophys. Res. Lett., 34, L19807, doi:10.1029/2007g1030752, 2007.

Volkamer, R., Ziemann, P. J., and Molina, M. J.: Secondary Organic Aerosol Formation from Acetylene $\left(\mathrm{C}_{2} \mathrm{H}_{2}\right)$ : seed effect on SOA yields due to organic photochemistry in the aerosol aqueous phase, Atmos. Chem. Phys., 9, 1907-1928, doi:10.5194/acp9-1907-2009, 2009.

Vrekoussis, M., Wittrock, F., Richter, A., and Burrows, J. P.: Temporal and spatial variability of glyoxal as observed from space, Atmos. Chem. Phys., 9, 4485-4504, doi:10.5194/acp-9-44852009, 2009.

Vrekoussis, M., Wittrock, F., Richter, A., and Burrows, J. P.: GOME-2 observations of oxygenated VOCs: what can we learn from the ratio glyoxal to formaldehyde on a global scale?, Atmos. Chem. Phys., 10, 10145-10160, doi:10.5194/acp-1010145-2010, 2010.

Washenfelder, R. A., Young, C. J., Brown, S. S., Angevine, W. M., Atlas, E. L., Blake, D. R., Bon, D. M., Cubison, M. J., de Gouw, J. A., Dusanter, S., Flynn, J., Gilman, J. B., Graus, M., Griffith, S., Grossberg, N., Hayes, P. L., Jimenez, J. L., Kuster, W. C., Lefer, B. L., Pollack, I. B., Ryerson, T. B., Stark, H., Stevens, P. S., and Trainer, M. K.: The glyoxal budget and its contribution to organic aerosol for los angeles, california, during calnex 2010, J. Geophys. Res.-Atmos., 116, D00v02, doi:10.1029/2011jd016314, 2011.

Whalley, L. K., Edwards, P. M., Furneaux, K. L., Goddard, A., Ingham, T., Evans, M. J., Stone, D., Hopkins, J. R., Jones, C. E., Karunaharan, A., Lee, J. D., Lewis, A. C., Monks, P. S., Moller, S. J., and Heard, D. E.: Quantifying the magnitude of a missing hydroxyl radical source in a tropical rainforest, Atmos. Chem. Phys., 11, 7223-7233, doi:10.5194/acp-11-7223-2011, 2011.

Whitehead, J. D., Gallagher, M. W., Dorsey, J. R., Robinson, N., Gabey, A. M., Coe, H., McFiggans, G., Flynn, M. J., Ryder, J., Nemitz, E., and Davies, F.: Aerosol fluxes and dynamics within and above a tropical rainforest in South-East Asia, Atmos. Chem. Phys., 10, 9369-9382, doi:10.5194/acp-10-9369-2010, 2010.

Wilmouth, D. M., Hanisco, T. F., Donahue, N. M., and Anderson, J. G.: Fourier transform ultraviolet spectroscopy of the a (2)pi(3/2) $<-\mathrm{x}$ (ii3/2)-i-2 transition of bro, J. Phys. Chem. A, 103, 89358945, 1999.

Winklmayr, W., Reischl, G. P., Lindner, A. O., and Berner, A.: A new electromobility spectrometer for the measurement of aerosol size distributions in the size range from 1 to $1000 \mathrm{~nm}$, J. Aerosol. Sci., 22, 289-296, 1991.

Wittrock, F., Richter, A., Oetjen, H., Burrows, J. P., Kanakidou, M., Myriokefalitakis, S., Volkamer, R., Beirle, S., Platt, U., and Wagner, T.: Simultaneous global observations of glyoxal and formaldehyde from space, Geophys. Res. Lett., 33, L16804, doi:10.1029/2006g1026310, 2006. 